\title{
SLOVENSKO-HRVAŠKA DRŽAVNA MEJA V MEJIŠČU EVROPSKE UNIJE
}

\author{
dr. Filip Tunjić \\ Univerza na Primorskem, Fakulteta za humanistične študije, Oddelek za geografijo, \\ Titov trg 5. SI-6000 Koper \\ e-mail: filip.tunjic@fhs.upr.si
}

Pregledni znanstveni članek

COBISS 1.02

\section{Izvleček}

V svetu je sorazmerno malo državnih teritorialnih meja, ki bi imele le lokalni, meddržavni značaj. Avtor skuša ob Braudelovem zapisu, da »... pokrajina ni referenčni okvir raziskovanja, temveč je referenčni okvir raziskovanja le problem«, analizirati pomen slovensko-hrvaške državne meje $\mathrm{z}$ vidika politične geografije vmesnosti balkanske Evrope ter robnega in kontaktnega položaja teritorijev obeh držav, pri čemer njuna državna meja ostaja brez pomena in funkcije.

Ključne besede: Balkan, mejišče, imperijski teritorialni sistem, frontirizacija, EU, Rusija, Turčija

\section{STATE TERRITORIAL BOUNDARY AT THE EDGE OF THE EUROPEAN UNION: FRONTIERISATION OF SLOVENIA-CROATIA TERRITORY}

\begin{abstract}
There are relatively few of state territorial boundaries in the world being of only local, interest. Author tries, following Braudel's note that »lanscape is not referential framework of research but the referential framwork of research is only problem «, to analyse importance of Slovenia-Croatia state boundary. He does it through the political-geographic prism of betweenness of the Balkan's Europe that is of edge and contact position of territories of both countries, for what the state boundary looses both its importance and function.
\end{abstract}

Key words: Balkan, limitroph, imperial territorial system, frontierisation, European Union, Russia, Turkey 
"Dokler se neka iluzija ne razkrije kot zabloda, je njena vrednost popolnoma enaka vrednosti, ki jo ima realnost."

Jean Baudrillard

\section{UVOD}

Obsežne političnogeografske in drugačne znanstvene razprave v Sloveniji o slovenskohrvaški državni teritorialni meji, ki segajo vse do razgretja političnih strasti, so v glavnem obstale na že ustaljenih pristopih in metodah, le redke so zaznale nujnost premika od lokalnega diskurza k širšemu regionalnemu. Klemenčič navaja, da v Sloveniji »... niso bile upoštevane posebnosti njenega geopolitičnega položaja, niti vloga njene prehodnosti med Zahodno in Vzhodno ter Jugovzhodno Evropo« (Klemenčič 2009, 29). »Posvečati pozornost samo mejam med državami ni mogoče v svetu, v katerem se naglo razvijajo ... nove supranacionalne (blokovske) identitete kot skupine državnih enot ..." (Kolossov in O’Loughlin 1998). Enakemu diskurzu se pridružuje Zupančič z opazovanjem Jugovzhodne Evrope kot sorazmerno trajnega geopolitično nevralgičnega območja zaradi položaja »... presečišča številnih interesov«, ki so po svoji strukturi »... predvsem svetovna periferija« in jih je treba »... preučevati tudi geografsko v luči mednarodnih odnosov in preoblikovanja svetovne politične karte« (Zupančič 2006; 2009).

Razlogi za to so preprosti, in sicer so v evropski političnogeografski stvarnosti in njenih tokovih. Nujnost spremembe pristopa $k$ preučevanju vprašanja slovensko-hrvaške meje, in sicer z lokalnega na raven evropske geopolitične strukture v prostoru in času, temelji že v klasični političnogeografski epistemologiji. Že v Ratzlovi politični geografiji je vprašanje odnosov med teritorialnim osredjem in obrobo (periferijo) eden bistvenih elementov. Za Rokkana so odnosi med osredjem in periferijo, oziroma periferijami, prvina evropskih teritorialnih struktur političnih sistemov, ki se razvijejo v proces teritorialne ekspanzije (Rokkan in sod. 1999, 7). V Rokkanovem razdvajanju jedrnosti in perifernosti od državnosti je v zgodovinski perspektivi mogoče Slovenijo in Hrvaško ter druge balkanske državice najti le kot sestavino vzhodnega, perifernega območja zahodnoevropskega političnega osredja ter vmesnega območja konflikta med evropskim Vzhodom in Zahodom (Josipovič 2009; Tunjić 2004).

Več kot jasno je, da reteritorializacija Evrope pomeni spreminjanje geopolitičnih odnosov. Maastrichtski in schengenski sporazum sta usmerjena tako $\mathrm{v}$ razvezovanje državnega teritorija in razvrednotenje državnih teritorialnih meja v notranjosti EU kot v zvezovanje teritorijev na periferijah ali obrobjih v nove geopolitične, geostrateške in varnostne meje nasproti drugim geopolitičnim subjektivitetam s središčema v Moskvi in Ankari (Foucher 1998, 236; Laitinen 2003, 24-25). To pomeni, da nova evropska (neo)imperijska teritorialna struktura ne vključuje le projekta megakompleksa EU in evroatlantske superstrukture, temveč krepitev tudi drugih dveh glavnih evropskih geopolitičnih subjektivitet, Rusije in Turčije (Aalto 2002; Wæver 1997; Tunjić 2004; 2007). Za vmesna območja periferij, hegemonije in dominionov to neizogibno pomeni njihovo frontirizacijo. $\mathrm{V}$ povezavi s tem in v kontekstu centralnosti in perifernosti Kolossov in O'Loughlin (1999) ter Tunjić (2003; 
2004) uvajajo koncept mejišča (eng. limitroph), ki ga zaznamujejo gruče šibkih držav ter psevdodržav, navideznih (kvazi), uporniških in getovskih držav ter drugih šibkih državic, katerih usoda je povezana z izključevalnimi in omejevalnimi odnosi imperijskih osredij. $\mathrm{Ob}$ tem ne smemo mimo 'teritorijev prestopišč' (angl. gateway territories) in držav prestopišč (angl. gateway states), šarnirskih držav, ki jih uvaja Cohen v kontekstu nastopanja »... nove globalne geopolitične strukture« v 21. st. Gre za »... po površini in prebivalstvu majhne države, pogosto ležeče čez ključne dostopne poti ...,« pri čemer koncept 'regije-prestopišča' predstavlja lokalno razširitev koncepta 'držav-prestopišč' (Cohen 1999; 2002, 53).

Iz tega ni težko sklepati, da gre pri tem za spreminjanje funkcij DTM v funkcije teritorialnih meja širših funkcionalnih teritorialnih sistemov, česar institucionalni izraz je tudi EU. Vse prisotnejša raba pojmov, kot so 'Vmesna Evropa' oziroma 'Zwischeneuropa', 'Lands in Between', 'Europe in Between', 'Marching Lands of Europe', opozarja političnogeografsko znanost na potrebo po celovitejšem spoprijemu s samo teritorialno ontologijo politične teritorialnosti in teritorialnih meja ter teritorialnimi razsežnostmi stabilnosti in varnosti.

Navedeni procesi so temeljišče, na katerem Kolossov in O'Loughlin (1999) dokazujeta, da »... političnega razvoja ni več mogoče razlagati z značilnostmi politične meje med dvema sosednjima državama, temveč z lokacijo, ki jo ta meja zavzema kot intrinzični element svetovnega sistema«.

Iz povedanega se sama po sebi porajajo vprašanja o položaju in urejanju slovensko-hrvaške državne teritorialne meje. Od tod pomeni ta razprava začetek preverjanja domneve, da se pomen te meje izgublja zaradi utapljanja teritorijev obeh držav v funkcijo medimperijskega mejišča, ki se imenuje Balkan. Torej, za razumevanje vprašanj te meje ni treba iskati odgovorov v vprašanju meje niti v sporu med državama, temveč v evropskih in evrazijskih reteritorializacijskih in geopolitičnih razsežnostih.

Prispevek je obenem poskus iskanja odgovora na vprašanje, ki ga vsiljuje raziskava istega avtorja, namreč, kako je mogoče, da se je mejni spor med državama zaostril do stopnje, ko državi nista zmožni rešiti spora dvostransko in kličeta posredovanje EU? Pri tem se sklicujemo na to, da je v navedeni raziskavi slovensko-hrvaška meja pristala v skupini najmanj konfliktnih meja med 54 mejami Vmesne Evrope.

\section{PO SLEDEH ENE RAZISKAVE}

Ob graditvi teoretičnega konstrukta konfliktnosti DTM, merjeni v obdobju od leta 1900, je slovensko-hrvaška meja pristala v skupini najmanj konfliktnih v izbranem vzorcu 54 meja Vmesne Evrope (Tunjić 2004; 2004a; 2003). Tudi ko smo postavili konfliktnost državnih meja v odvisen odnos z 11 neodvisnimi spremenljivkami (dejavniki konfliktnosti DTM) in jo merili z metodo hierarhičnega razvrščanja, se je slovensko-hrvaška meja uvrstila v skupino osmih, ki smo jih lahko kategorizirali kot nizkokonfliktne (Tunjić 2004a).

Ob takšnemu rezultatu se zastavlja logično vprašanje, kako je mogoče, da se je lahko spor o poteku delov meje med novima državama po razkroju Jugoslavije tako zelo zaostril, da ga državi nista zmožni rešiti dvostransko.

V raziskovalni model za kvalitativno-kvantitativno merjenje vpliva različnih dejavnikov na konfliktnost in intenziteto konfliktnosti državnih meja smo med 11 spremenljivk oziroma 
dejavnikov konfliktnosti vključili tudi starost, način vzpostavitve, historičnost, geopolitične enote in položaj teh meja v imperijskih krogih, če omenimo le pomembnejše z vidika tega prispevka.

Kljub navedenemu predstavljamo le raziskovalno spremenljivko 'položaj DTM v imperijskih krogih'. Prav tako se ne ukvarjamo z definicijami in merjenji konfliktnosti slovenskohrvaške meje, temveč poskušamo s predstavitvijo dejavnika le nekoliko osvetliti problem tega prispevka.

\section{I. Položaj DTM v evropski imperijski strukturi}

Že na začetku raziskave je kazalo, da bo vnos dejavnika 'položaj DTM v imperijskih krogih' kot neodvisne spremenljivke $\mathrm{v}$ raziskovalni model med najbolj tveganimi dejanji. Operacionalizacija in testiranje modela sta to potrdila. Za podlago operacionalizaciji spremenljivke smo vzeli načelno zgradbo imperijskega sistema in projekcijo nove evropske geopolitične zgradbe. Pri konstrukciji spremenljivke smo se naslonili na razumevanje reteritorializacije v Evropi ter mejišča med nastopajočimi imperiji v novi evropski geopolitični zgradbi. Gre za zgradbo, v kateri skušajo osredja treh glavnih geopolitičnih subjektivitet-EU, Turčije in Rusije - oblikovati oziroma vzpostaviti in razširiti svoje imperijske funkcionalne teritorialne sisteme ter doseči varnostne meje, ki bodo ločene od uradnih meja teh sistemov (Foucher 1998). Domnevali smo, da so pomembnost, status in usoda vsake DTM odvisni od njenega položaja glede na naravo in moč centripetalnih in centrifugalnih sil v teritorialnih orbitah imperijskih osredij (Wæver 1997; Tunander 1997; Hassner 1997; Agnew 1999). Od tod smo definirali hipotezo, da konfliktnost DTM narašča 1) z njihovo oddaljenostjo od imperijskega osredja in 2) s položajem meje v krogih dveh ali več imperijev hkrati, oziroma s prepletom interesov in vpliva več osredij v območju konkretne meje. Pri oblikovanju merske lestvice smo analizirali in ugotavljali položaj vsake DTM v geopolitični zgradbi treh imperijev, pri čemer smo si tudi dovolili 'deformacije' krogov načelne strukture, s pogledom v prostor pa smo upoštevali sorazmerno jasne interese, ki so jih že izrazila, jih izražajo ali je precej verjetno, da jih bodo izrazila omenjena imperijska osredja (ceteris paribus).

Pearsonov koeficient korelacije med spremenljivko in konfliktnostjo DTM v našem primeru ni izražen in ni značilen ter je negativen $(r=-0,12 ; p=0,4)$. Tudi korelacije spremenljivke $\mathrm{z}$ drugimi spremenljivkami v modelu so večinoma šibke in neznačilne. Tako je tudi rezultat raziskave pritrdil sumu v ustreznost in zadostnost operacionalizacije spremenljivke. Verjetno se je treba vprašati o kompleksnosti spremenljivke in zmožnosti kakovostne ter dovolj obsežne identifikacije kazalcev, 'prevajanja' kvalitativnega znanja v kvantitativno ter obstoj neidentificiranih linearnih in nelinearnih korelacij, ki bi jih kazalo ugotavljati ter raziskovati $\mathrm{z}$ več različnimi pristopi in metodami.

\subsection{Primer - starost, način nastanka in položaj DTM}

Nekdanja jugoslovansko-italijanska državna meja je dobra ilustracija pomena dejavnika 'položaj v imperijskih krogih', pa tudi drugih navedenih dejavnikov. Primer kaže, kako imajo lahko strateški interesi širših ideoloških in teritorialnih osredij odločilen vpliv, ter kako 
lahko v takih primerih dejavniki in argumenti sosednjih držav odpovedo in štejejo malo ali nič. Meja s sedanjim potekom je nastala po drugi svetovni vojni in je, tudi če bi upoštevali rapallsko mejo, mlada meja. Ker o njej niso odločali interesi dveh sosednjih držav, temveč le strateški interesi dveh osredij bipolarne varnostne ureditve v Evropi, vprašanj te meje nista mogli rešiti ne versajska konferenca leta 1919 in ne pariška mirovna konferenca 1946/47. Moralo je miniti 30 let po vojni, da je šele Konferenca o varnosti in sodelovanju v Evropi (KVSE) ustvarila ugodne razmere na evropsko-evrazijski oziroma globalni ravni, ko je bilo leta 1975 mogoče doseči dvostranske osimske sporazume. Da so bili interesi Jugoslavije in Italije kljub pripadanju dvema poloma evropske varnostne strukture bolj kompatibilni kot interesi širših varnostnih struktur, priča med drugimi dejstvo, da je prav jugoslovanskoitalijanska meja postala dokaj hitro 'najmehkejši' segment 'železne zavese', ki se je raztezala po Evropi od Jadranskega do Baltskega morja, od petdesetih let dalje pa od Črnega morja do severa Jadranskega in od tod do Baltskega morja.

Primer seveda govori o urejanju državnih teritorialnih meja v Evropi v razmerah »... strogo regulirane, statične ali fiksne ureditve uvrstitev in skupin«, temelječe na 'dinamični izenačenosti' (Cohen 1994), ko ni bilo možnosti za spremembe z vojno, revolucijo ali državljansko vojno'. Po koncu hladne vojne sta Evropa in svet prešla v stanje, v katerem sta negotovost in nepredvidljivost postali najbolj resni grožnji mednarodni varnosti. Po dvajsetih letih, ko so se varnostni problemi, ki jih je Zahod pospešeno izvozil na Vzhod, začeli tako kot pred sto leti vračati kot bumerang, od koder so prišli, je postal položaj vendarle precej bolj predvidljiv.

\subsection{Lastnosti DTM glede na geografski položaj teritorijev, ki jih razmejuje}

Če se preselimo na politično teritorialnost, zlahka pridemo v polje geopolitike, ki jo je mogoče na splošno označiti kot ciljno orientirano politično teritorialno vedenje, na katerem temelji geopolitični položaj nekega območja oziroma politične enote. Ko pa pri vrednotenju geopolitičnega položaja neke lokacije govorimo posebej o političnih in strateških vsebinah, je treba uporabiti pojem geopolitičnega in geostrateškega položaja. Od tod je geopolitični položaj vrsta geografskega položaja, ki upošteva predvsem tiste dejavnike, ki so pomembni za položaj kake države ali območja držav v širšem teritorialnem sistemu. Poznamo nekaj značilnih vrst geopolitičnega položaja, kot so tamponski, položaj v obkrožitvi, obmejni ali robni, mejni (mejiščni, frontirni), stični ali kontaktni ipd. Čistih' med njimi skoraj ni, ker se praviloma med seboj prekrivajo, vključujejo in izmenjujejo ter se izražajo na lokalni, regionalni, superregionalni in globalni ravni. Pojem geostrateškega položaja je blizu pojmu geopolitičnega, le da upošteva tudi pomembne vojaške in strateške dimenzije na regionalni ali globalni ravni. Za oceno geostrateškega položaja se upoštevajo številni naravnogeografski in družbenogeografski dejavniki, kot so naravni dejavniki vojskovanja, poselitvena in gospodarska razpršenost ali koncentracija, izpostavljenost smerem dostopa do naravnih bogastev, geografija prometno-transportnih značilnosti, položaj glede na strateške interese politično-vojaških zavezništev idr.

\footnotetext{
${ }^{1}$ Blainey $(1988,11-12)$ je označil revolucijo kot substitut za vojno, vojno pa kot revolucijo proti delu mednarodne ureditve.
} 
Temeljna funkcija politične teritorialne meje je geopolitična - posredovanje in ločevanje med politično-teritorialnimi subjekti v prostoru. S spreminjanjem politične družbe, geografskega, geopolitičnega in geostrateškega okolja ter položaja nekega območja se spreminjajo tudi vloga in funkcije političnih meja v njem. »Sodobne meje niso le preproste črte na zemljevidih, neproblematične danosti političnega življenja, kjer ena jurisdikcija preneha in se druga začne; so središče za razumevanje političnega življenja ... Meje [angl. frontiers] med državami so institucije in procesi ..., meja je temeljna politična institucija .... (Anderson, M. 1996, 1).

Ali ta zapis torej nasprotuje zapisanemu v okviru domneve, da se pomen slovenskohrvaške meje izgublja zaradi utapljanja teritorijev obeh držav v funkcijo medimperijskega mejišča in da razlogov za spor o meji ni treba iskati v vprašanju meje? Odgovor lahko poiščemo pri pionirju Ratzlu, ki je ustvarjal politično geografijo v času imperijev in je lahko razumel državo predvsem kot imperij. »Mejna obroba je realnost, mejna črta je abstrakcija ...«, to obrobo pa sestavljajo trije periferni teritorialni pasovi - dva obrobna dela teritorijev sosednjih držav in osrednje pasovno območje med njima, na katerem se dve državi zlivata, je zapisal. »Rast in nazadovanje kakega teritorija se izražata ne samo v obliki in varovanju obstoječe meje, temveč se na njej rast ali nazadovanje pripravljata in naznanjata .... Aktualne meje odsevajo samo postanek v neprekinjenem gibanju, ki valuje naprej in nazaj...« (Ratzel 1897, 538, 540, 578, 599, 605). Zaradi tega so državne meje dinamične - kjer so fiksne, so označile le začasno ustavitev teritorialne širitve. Vsaka slabitev vezi med državnimi mejami in državnim jedrom ${ }^{2}$ slabi državo, rezultat pa je izguba meje in priključitev države k sosednji. Ne Hrvaška in ne Slovenija tako zaradi velikosti kot oblike teritorijev ne moreta razmišljati v Ratzlovih kategorijah 'tripasovnih' meja.

Če je Ratzel tako razmišljal o življenju evropskih imperijev (držav) nekoč, je težko zanikati vrednost njegovih trditev tudi za današnji čas. Če gre verjeti Ritterjevi ciklični teoriji rasti države, indoevropski doktrini o cikličnem gibanju zgodovine Kali Yugi, Spenglerjevi ciklični teoriji zgodovine o vzponih in propadih različnih kultur, Kennedyjevi teoriji rasti in propada velikih sil, potem je mogoče le pritrditi, da pomeni konec hladne vojne 20. st. le vrnitev Evrope iz začasnega hladnovojnega suspenza tokov v normalno razvojno stanje (Tunjić 2004; 2003). K temu bi lahko dodali, da smo na neki točki sklenitve zgodovinskega cikla obdobij svetovnih redov, in sicer: 1) fevdalnih imperijev in 'držav' od leta 1648 do 1815; 2) nacionalnih imperijev držav ter držav od 1815 do 1945; 3) vojaškopolitične in ideološke bipolarne hegemonije supersil ter 4) nastopajočega sistema imperijev in 'držav'.

Politična teritorialna meja je nedvomno politična institucija, politični proces in politični odnos (Anderson, M. 1996; Paasi 1999), vendar vse manj »zamišljena vertikalna črta-zavesa« in čedalje bolj konkreten politični prostor. Pojem 'državna meja' v slovenskem in 'državna granica’ v hrvaškem jeziku imata enak pomen: v obeh jezikih je »namišljena vertikalna zavesa, ki omejuje suverene države v zemlji, na zemeljski površini ter v zraku« (Grčić 1989, 88). Enako označuje tudi pojem 'boundary' v angleškem jeziku, ki ga ne bi smeli zamenjevati $\mathrm{s}$ tradicionalnim pojmom 'frontier' in ne $\mathrm{z}$ ameriško različico, izraženo v pojmu 'border'. Webb označuje z 'boundary' mejo med ZDA in Kanado, ki je stabilna, nekonfliktna in z manj nezakonitosti, z 'border' pa mejo med ZDA in Mehiko, ki je konfliktna in z več nezakonitosti

\footnotetext{
${ }^{2}$ Državno (imperijsko) jedrno območje je eden ključnih elementov Ratzlovih analiz države.
} 
(Webb 1952). Slednja po varnostni plati ni več le 'zamišljena črta' skrajnega perimetra, do katerega se razteguje suverenost, temveč mejno pasovno območje, ki po Ratzlu omogoča valovanje meje sem in tja. Ustrezno geografskemu, geopolitičnemu in geostrateškemu položaju bližnjih državnih teritorijev je DTM tudi referenčna črta $v$ strategijah širših funkcionalnih teritorialnih sistemov. Zato omenjenega nasprotovanja hipotezi ni, temveč še bolj pritrjuje tezi o transformaciji slovensko-hrvaške meje v simbolično mejo na teritorialnem obrobju imperija in znotraj medimperijskega balkanskega mejišča.

Nujnost prehoda političnogeografskih razprav o političnih mejah k upoštevanju prostorskih dimenzij meje, 'njene podkožice', bi rekel Ratzel, ni ostala neopažena niti v znanstvenem opusu Slovenije in Hrvaške. Vprašanje razlikovanja med mejami in mejišči je načel Pavić leta 1989: DTM (državno granico) je jasno opredelil kot črto, ki razmejuje suverenosti dveh držav, vojaška bloka v zunanjem smislu ter teritorialne enote v notranji teritorialni organizaciji držav. Z aktualiziranim pojmom 'međa, medja' pa je označil prostor, ki je med ali vmes, ima prostorske dimenzije, je otipljiv in je hkrati v razmerju do kake celote in drugih delov. V slovenskem jeziku in nekoliko širšem kontekstu/okviru je Tunjić aktualiziral pojem 'mejišče' (2004) tako, da ga je opredelil kot območje prekrivanja in prepletanja dominionov, hegemonije, 'neodvisnih' šibkih držav in drugih medimperijskih struktur dveh ali več osredij oziroma razvojnih središč. S pojmom je označil povrnitev Vmesne Evrope in s tem vrnitev Evrope v normalno stanje, ki opušča stanje začasnega suspenza tokov, ki je zaznamoval skoraj vse 20. st. (Tunjić 2003; 2004). Ob tem vrača tudi nekoč v slovenščini znani pojem 'frontir' in z naslonitvijo na večjezikovno etimologijo pojma opozarja na frontirizacijo prostora Vmesne Evrope in Balkana (Tunjić 2009a). Funkcionalni pojmi v francoskem jeziku 'frontière', 'front', 'marche', 'limes' vsi po vrsti izhajajo iz starega samostalnika 'front', medtem ko 'front' vendarle pomeni 'frontno črto' v vojaškem pomenu, ki je običajna sestavina konfiguracije sodobne Evrope od Moldavije do nekdanje Jugoslavije (Foucher 1998, 235).

\subsection{Naprej k preteklosti}

»Nazaj k prihodnosti« (Mearsheimer 1990) ne pomeni le vračanja Vmesne Evrope »... v 19. st. ideologij, osredotočenih na graditev nacionalnih držav« (Rupnik 1994). Da »preteklost gradi prihodnost« (Posener 2007, 180), priča že bežna primerjava današnjih političnih zemljevidov s tistimi z začetka 20. in 19. st. (Chaliand, Rageau 1993, 34; Magocsi 2002, 84-87, 93-95; 118-129; Povijest... 1990, 623). Le glavni akterji z Zahoda so nekoliko 'drugi' - poleg ruskega in turškega je namesto germanskega oziroma habsburškega sedaj 'evropski' ali evroatlantski oziroma politični Zahod, za katerega je prednostna naloga geopolitičnega megaprojekta 'evropeizacija' Vzhoda. Vanj sta ujeti tudi 'nova' geografija Balkana ter njegova prihodnost preteklosti (slika 1).

Z reteritorializacijo Evrope na prehodu stoletij se Balkanu ni zgodila Evropa brez meja, zgodil se je Balkan z več meja. »Ni težko ugotavljati, da bi pojav 'balkanizacije', t.j. ustvarjanje vrste malih, ekonomsko in politično šibkih ter med seboj nasprotujočih si državic na prostoru Jugovzhodne Evrope predstavljalo .... Razcefranost v naših pogojih bi pomenila neizbežen vstop v blokovske strukture, z vsemi možnimi negativnimi posledicami, ki bi 
lahko iz tega nastopile«, je nekoč vizionarsko ugotavljal eden pionirjev graditve politične geografije v Jugoslaviji Radovan Pavić $(1973,143)$ in verjetno nehote opredelil prihodnost snopiča ljudstev, narodov in držav na južnem kraku Vmesne Evrope.

Pavić ni predvideval, da bodo morala ljudstva in nove države prositi za vrnitev v (politično) Evropo. Po 'osvoboditvi’ narodov Vzhodne Evrope in po sprejetju Pariške listine

\section{Slika 1: Vrnitev k prihodnosti}

Figure 1: Back to the future

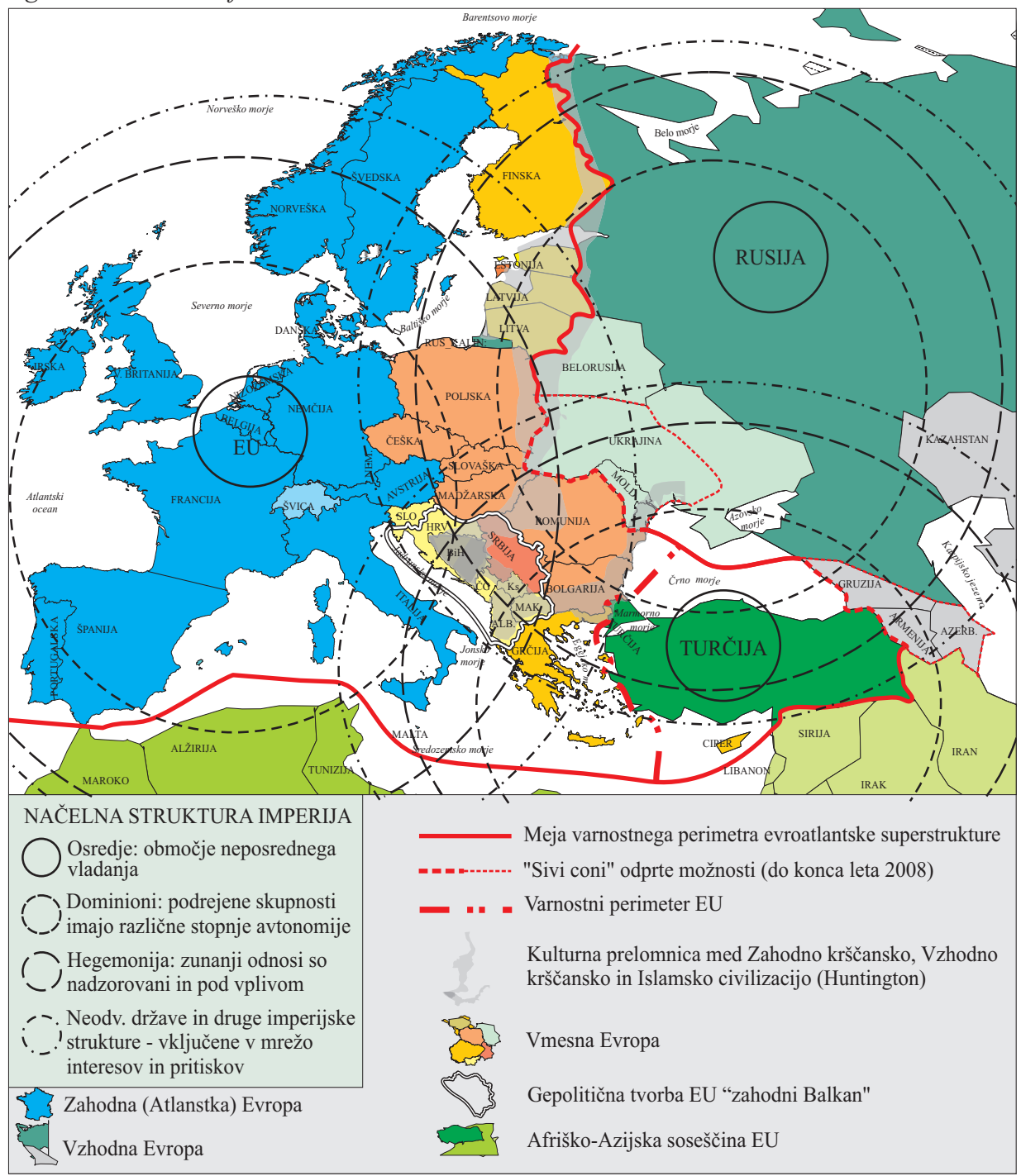


za novo Evropo leta 1990 je razvoj odnosov na Balkanu postal 'trajen dejavnik' stabilnosti in varnosti narodov, ki »... po eni strani pospešuje njihove zahteve do Evrope, po drugi pa omejuje možnosti za politično delovanje in jih vrača predvsem na območje Balkana.» (Vukadinović 1995). »... Balkan ... turbulentno mejišče Jugovzhodne Evrope«, je »danes ponovno aktivno med 'Evropo' in Rusijo in med 'Evropo' in muslimanskim svetom, ter predstavlja 'bojno cono’ med novimi metaforičnimi imperiji.« Poleg avtentičnih balkanskih ljudstev, ki iščejo svoje nacionalne priložnosti in »pogosto možnost golega obstoja«, se v aktualnih geopolitičnih tokovih na ta prostor aktivno vračajo zunanji subjekti s svojimi navzkrižnimi interesi, to so Nemčija, Rusija, Italija, Francija, ZDA in tudi Turčija (Cviic 1997; Vukadinović 1995; Tunjić 2004; 2005; 2009a).

»Najmočnejši zakoni, ki upravljajo državo, so geografski« in »Azija se začenja na Landstrasse«, kraljevski cesti, ki pelje od Dunaja proti Budimpešti, je pred 190 dejal Metternich in tako zasejal trajno vprašanje, zakaj je tako težko imeti balkanske dežele za evropske. Kakor koli, ostaja dejstvo, da so vsa ljudstva Balkana gradila svoje državnosti po delih ali v celoti na robovih in v mejišču evropskih imperijev.

\section{3. 'NOVA' EVROPSKA IMPERIJSKA GEOPOLITIČNA STRUKTURA}

Zakaj je treba teritorialne sisteme Evropske unije, Turčije in Rusije ocenjevati kot imperije? Wæver $(1997,77)$ pravi, da 'perspektiva treh imperijev' ne narekuje, da morajo biti podobno organizirani, niti da so enako močni. Lahko govorimo o dveh imperijih, o enem močnem in dveh šibkih. Vendar bistvo ni v tem, da so enako močni, temveč da vsak med njimi uspešno oblikuje gravitacijski center, dojemanje sebe kot centra, ki v svojo orbito priteguje druge države, in ne nazadnje, da se začenjajo obnašati drugače, kot bi se, če bi bili samo periferni glede na 'evropsko' družbo.«

\section{I. Evropska unija}

»Če Evropska unija želi biti resna politična igralka v hitro spreminjajočem se svetu, se mora odločiti za geopolitično strategijo, ki bo temeljila na lokacijah njenih teritorialnih interesov. Definiranje njenih meja, geopolitičnih prioritet in zavezništev bo močno poudarilo njeno sposobnost prinašanja lastne teže v svetovni red«, sporoča Thomann, znanstveni svetovalec za geopolitiko in geostrategijo v Evropskem inštitutu za mednarodne odnose v Bruslju (Thomann 2010). Geopolitika je evropska prvina in večina definicij Evrope izhaja iz zgodovinskega pregleda geopolitike (Hay 2003). Se je današnja Evropa znebila logike in filozofije frontirjev in mejišč? EU izraža koncept nove kolektivne varnosti tako, da poziva $\mathrm{k}$ tesnejši integraciji vojaških in varnostnih zadev ter tako k reinkarnaciji Svete alianse. Tokrat, v psevdoglobaliziranem svetu, poskušajo zahodnoevropske velike sile s projekcijo 'združene moči' prek Bruslja »risati glavni strukturni razvoj in proces v sodobni Evropi v sferi prostorsko in geografsko obarvanih politik« (Aalto 2002). Glede na vzpostavljanje ruskega in turškega imperijskega osredja, oblikovanje odnosov med EU, Turčijo in Rusijo ter na vse močnejšo razpoko med evropskim in ameriškim stebrom evroatlantske superstrukture, je 
mogoče govoriti tudi o reinkarnaciji Koncerta evropskih sil. Njegova temeljna ideja je bila zagotavljanje ravnotežja moči in stabilnosti med evropskimi imperiji. Če se je katera koli glavnih sil teritorialno okrepila, so bile druge vodilne sile deležne ustreznih nadomestil na račun majhnih držav na vmesnih ali perifernih območijih. Ustanoviteljice Koncerta so bile Združeno kraljestvo, Avstrija, Rusija in Prusija, pozneje se je pridružila Francija. Leta 1856 je bila vanj sprejeta tudi otomanska Turčija, dvajset let pozneje pa je Avstrija zasedla BiH in postavila vojaške postrojbe v Sandžaku.

Ni dvoma, da poteka projekt EU v smeri oblikovanja hierarhičnega sistema držav. Ta namesto tradicionalne države s 'konstantno energijo' in polno suverenostjo do mejnih črt nastopa kot kompleks, ki pušča Evropejce, predvsem tiste proti vzhodnim in jugovzhodnim robovom EU, v neredu brez suverene oblasti, brez stabilne in jasne strukture sistema suverenih držav, jih prepušča 'ureditvi', ki spominja na srednjeveško (Wæver 1997, 61). To je le korak po poznem srednjem veku, ko so bili Evropejci obsedeni bolj z ideologijo krščanstva kot z Evropo, ko je bila Evropa samo del širšega krščanskega koncepta (Christianitas). Vladanje je bilo utemeljeno strogo teritorialno, ločitvenih črt ni bilo, temveč so bila le ločitvena območja (Buchanan in Moore 2003, 7). Pojem Evrope kot kulturne in politične skupnosti in ne več samo 'zahodnega krščanstva' ali 'zahodne civilizacije' ali 'Zahoda', se je pojavil šele z renesanso kot čustveni izraz evropskosti, pa še to ob križarskih vojnah. Danes se za mnoge, tako kot za Huntingtona (1996, 158), Evropa končuje tam, »kjer se končuje zahodno krščanstvo in se začenjata islam in pravoslavje«. Seveda ta meja ni črta, temveč območje, široko najmanj od pravoslavnih cerkev in džamij ter centrov na Dunaju, v Ljubljani, Trstu, Budimpešti, Zagrebu do katoliških cerkev v Beogradu, Subotici, Novem Sadu, Skopju, Sofiji, Bukarešti, Carigradu, Kišinjevu ...

Wæver (1997) vidi v EU oblikovanje geopolitične strukture z vsemi značilnostmi imperija, s hierarhičnim teritorialnim redom, v katerem v koncentričnih krogih najdejo svoje mesto območje osredja (centra), krog dominionov, krog hegemonije in krog 'neodvisnih' držav ter drugih medimperijskih struktur. Tudi Taylor (1997, 110-111) vidi v EU značilnosti imperijskega sistema, v katerem delujeta dva tipa držav - osredje in periferija (obrobje), v obeh pa delujeta po dva razreda - vladajoči in vladani. Agnew (1999) ugotavlja, da geopolitična rekonstrukcija Evrope poteka s trojno prostorsko delitvijo: z oblikovanjem jedrne Evrope, periferne Evrope na čakanju in zunanje Evrope, ki je izključena iz potencialnega članstva, vendar odprta za kupčije med jedri. Anderson pravi, da ima graditev EU imperijske cilje in tendence in s tem visoko stopnjo diferenciacije ter neenakosti glede na variiranje njenih meja od natančnih črt do razcefranih, nerazločnih območij, ki vključujejo tudi šibkost odnosov med teritorijem in suverenostjo (Anderson, J. 2007).

Ko je poskus širitve EU trčil s strateškimi interesi Rusije v skupni ‘bližnji soseščini', je postalo jasno, da bo treba graditi nove odnose z obema osredjema. Ker nadaljnja širitev ni bila več realna opcija, je za voditelje EU postal 'prvi strateški cilj Unije' zgraditi 'krog prijateljev' (Prodi) ali »krog dobro vodenih držav vzhodno od Evropske unije, od Balkana do Kavkaza«, (Solana, Patten) in na mejah Sredozemlja (Tunjić 2009, 100). Gre za »... lok nestabilnosti, ki se razteza od Belorusije do Ukrajine, Moldavije, zahodnega Balkana, Južnega Kavkaza, Bližnjega vzhoda in Severne Afrike, od katerega se EU ne sme umikati.« (Grant; po Tunjić 2009, 101). 
Na jugovzhodu bo treba najti kompromis s Turčijo, najmanj glede projekcije skrajnega teritorialnega perimetra evroatlantske superstrukture. Ta s potekom od Gibraltarja do ruskega polotoka Kola vključuje tudi Turčijo (Mouritzen in Wivel 2005, 199), medtem ko EU, tudi nasproti ameriškemu polu, želi 'EU-jske strukture' s Turčijo zunaj. Med 'Nami' in Turčijo kot geopolitično 'Drugim' v evropski geopolitični strukturi je nujno vmesno, prehodno in predvsem geopolitično determinirano območje, to je Balkan. »Evropa ostaja krščanska trdnjava bolj kot se njeni ljudje zavedajo. Zahod je preplavljen s strahom pred islamizacijo Evrope,« opozarja Jenkins (2007), sicer profesor zgodovine in religijskih študij na Pennsylvania State University.

Kakor koli, konceptualizacija močno spominja na oblikovanje ločnice med Vzhodom in Zahodom, ki ji je nekoč Kjellen dejal 'velika kulturna ločnica', v čemer vidi Foucher (1998) strategijo limesa, to je ustvarjanja varnostnega glacisa iz držav Vmesne Evrope na robovih EU. Tako schengenska kot zunanja meja EU sta iz zornega kota kritične varnostne misli varnostni meji oziroma novi funkcionalni meji s prednostnim geopolitičnim, geostrateškim oziroma varnostnim namenom. EU je politično/geopolitični konstrukt in njen geopolitični boj za 'nove strateške meje' poteka predvsem na obrobjih oziroma na robovih in v 'bližnji soseščini' onstran meja EU. Odziv EU na »varnostne pojave, ki presegajo nacionalne meje«, z reševanjem čim večjega dela težav 'že v državah izvora' spominja na Haushoferjevo filozofijo topov z dometom čim dlje od uradnih meja takratne nemške države.

Pripustitev Romunije in Bolgarije v EU leta 2007 je klasičen primer geopolitične in geostrateške motiviranosti, oziroma tega, da so o sprejemu držav v Unijo odločali strateški razlogi Unije in ne pripravljenost držav za članstvo. Z vključitvijo teh držav je želela EU rešiti vsaj tri vprašanja: 1) na vsak način preperečiti nadaljevanje vpliva Rusije in Turčije na procese na t.i. zahodnem Balkanu; 2) odmakniti Rusijo od nestanovitnega območja zahodnega Balkana in območje spraviti v karanteno, kjer bo ostalo med dolgotrajno operacijo vračanja območja v tamar EU, ter 3) absorbirati vse evropske države nekdanjega Varšavskega sporazuma in tako končati vse njihove formalne zveze, ki so jih imele s Sovjetsko zvezo. Še bolj očiten primer je bil sprejem treh nekdanjih sovjetskih pribaltiških republik Litve, Latvije in Estonije.

Del istega koncepta je tudi zahodni Balkan, geopolitični konstrukt EU, z namenom ponuditi državam Balkana zahodno od Bolgarije in Romunije (pojem Vzhodni Balkan se ne pojavlja) simbolno avreolo pripadanja političnemu Zahodu. Ta je po Zupančiču za EU povsem operativnega značaja', namenjen krepitvi in naposled doseganju popolne prevlade nad Balkanom, tudi zaradi strateške vrednosti ozemlja (Zupančič 2009, 98). Uporaba termina nima ne v geografiji in ne v politični geografiji nobene strokovne podlage.

Doslej je EU še lahko brez hitenja samozavestno puščala t.i. zahodni Balkan v položaju zadrževanja, obkroženega z drugimi članicami zveze NATO in EU, vedoč, da nimajo druge izbire kot pot proti EU. Vendar entuziazem, s katerim Moskva in Ankara obnavljata vpliv na Balkanu, močno skrbi EU.

\subsection{Rusija}

Rusija je bila vsaj 300 let središče procesov v Evraziji. Po manj kot desetletju 'Rusije na 
kolenih' po razkroju Sovjetske zveze, se je začela Rusija v evrazijskih geopolitičnih odnosih vračati na svoje mesto evrazijskega gravitacijskega središča.

Kot edina resnično evrazijska država in največja kontinentalna sila na svetu se Rusija zaradi svojega geografskega, kulturnega in gospodarskega položaja v vzhodni polovici Evrope in Aziji »ne more izogniti svoji geopolitični usodi vzdrževanja svojega teritorija ... z boji za vpliv v strateško vredni evrazijski regiji« (Wijnants 2006). Med strateškimi komponentami tega boja je vzdrževanje tamponskih območij in klientnih držav v neposredni in daljši soseščini. Razdeljenost Evrope na tri geopolitične areale, ki »na celini vzpostavljajo trajna območja napetosti, nastajajo na nestalnih in nenehno spremenljivih mejah med evropskim Zahodom in Srednjo Evropo na eni strani in med Srednjo Evropo in Rusijo (Evrazijo) na drugi strani ...«, je aksiom ruske geopolitične misli o Evropi (Matić 1995, 290-291). Odnosi Rusije s Turčijo in rusko-turške vojne so bile vedno tudi vojne ostalih evropskih sil - Velike Britanije, Francije, Avstro-Ogrske, Nemčije, Italije idr. Rusija je bila akter vseh porazov Osmanskega imperija in propad Osmanskega imperija je pomenil hkrati propad ostalih evropskih imperijev, vendar hkrati vzpona Rusije/Sovjetske zveze. Zgodovina prisotnosti Rusije na Balkanu je hkrati zgodovina ostalih evropskih sil, ki so družno vladale Evropi.

Zlasti po revitalizaciji vpliva v 'prvem strateškem krogu' soseščine je Rusija leta 2007 razglasila novo fazo zunanje politike, prek katere bo nadaljevala vlogo »uravnoteževalca $v$ globalnih zadevah z uporabo svojih zmogljivosti ... (Lavrov 2007). Vojaška intervencija v Gruziji avgusta 2008 in nova vojaška doktrina sta pokazali odločenost in obenem transparentnost zunanje in varnostne politike Rusije. Medtem je Rusija že bila opravila prenos t.i. 'zamrznjenih konfliktov' iz svoje ‘bližnje soseščine' v sam 'trebuh' EU (Bosna in Hercegovina, Kosovo, Makedonija in še nekateri drugi bi se lahko začeli taliti). Nastopila je $\mathrm{z}$ energetsko in denarno diplomacijo. Obisk predsednika Rusije D. Medvedjeva v Srbiji ob 65. obletnici osvoboditve Beograda z milijardo evrov v žepu za posojila in investicije ter njegov pogovor o strateškem partnerstvu s Srbijo, je močno znamenje. Kratko po tem obisku v Beogradu je S. Lavrov, ruski minister za zunanje zadeve, med obiskom v BiH pozval k zaprtju Urada visokega predstavnika, mednarodnega upravitelja Bosne in Hercegovine. Rusija se je usidrila tudi v stanje v Bosni in Hercegovini kot garant Republike srbske. Ob vsem tem Rusija dobo ve, da se lahko tudi v primeru EU paradoks evropske evolucije kadar koli podaljša, da se Evropa nenehoma integrira, a se nenehno razhaja ob srečanju z realnimi strateškimi vprašanji.

V EU je vendarle prevladalo zavedanje strateške nujnosti, da »... je moč Rusije trajno ukoreninjena tako v Aziji kot Evropi in da mora [Nemčija] narediti vse, kar je v njeni moči, da integrira Rusijo v staro celino, kolikor je mogoče blizu in polno« (Bahr 2008). V EU so spoznali, da lahko le skupaj z Rusijo računajo na uresničitev svoje strateške vizije EU kot akterja globalnih strateških tokov (Posener 2007). Na Zahodu so spoznali, da bo vrnitev odnosov z Rusijo na začetek (peregruzka) boljše dejanje, kot vztrajanje pri ignoriranju strateško nepogrešljive Rusije. Dojeli so tudi, da je bolje razvijati 'vzhodno partnerstvo' EU tako, da mu bo naklonjena tudi Rusija, kot pa nadaljevati dosedanjo izključevalno Evropsko sosedsko politiko (ENP). Danes je Rusija nesporen akter globalnih in evrazijskih geopolitičnih odnosov ter nosilka geopolitične moči tudi v Jugovzhodni Evropi. Tega se zavedajo v EU, prav tako pa tudi opozorila: »Evropa pohiti, ali zamudi stoletje Azije.« (Mahbubani 2009). 


\subsection{Turčija}

Tudi Turčiji so nove razmere ponudile izziv za rekonstrukcijo geopolitične subjektivitete v povezavi z njeno zgodovino in religijo (Wæver 1997, 76), pri čemer se narodno in religijsko sorodstvo raztegujeta daleč zunaj meja države. Turčija je bikontinentalna ${ }^{3}$ država »... na ključni lokaciji in križišču treh celin ima edinstveno geopolitično identiteto v okviru te regije ... predstavlja središčno silo in žarišče ne samo za Balkan ...« (Leicht 1999). Tudi Turčija je jedrna država enega izmed evropskih imperijev, ki so nekoč vladali Evropi in prek Koncerta evropskih sil vzdrževali evropski geopolitični red. Zlom Osmanskega imperija je označil tudi začetek zloma koncerta. Turčija je sestavni del evropske zgodovine in politike ter geografije, zato ni mogoče govoriti o Turčiji kot tujku v evropskem telesu. Nobenega razloga ni, da Turčija ne bi videla v retrogradnem procesu reimperializacije Evrope priložnosti za samorevitalizacijo sebe kot enega evropskih imperijskih osredij in regionalne sile.

Nekdanji premier Demirel ni pozabil spomniti, da »... Turčija leži v samem epicentru velike geografije in nove geopolitike Evrazije. Ta 'evrazijska realiteta' od Jadranskega do Kitajskega morja je bila poseljena z 200 milijoni ljudi, ki so delili skupne korenine, jezik, religijo in kulturo« (Winrow 1995, 15).

Balkan je že na začetku krize v Jugoslaviji postal za Turčijo vadišče močnega političnodiplomatskega delovanja. Turčija je bila prva med donatorji muslimanom v Bosni in Hercegovini, prva je Makedoniji ponudila varnostna zagotovila, v Bolgarijo, Albanijo, Hrvaško, Bosno in Hercegovino ter v 'kosovsko krizo' je vstopila s političnimi in vojaškimi inštruktorji ter opremo (Vukadinović 1995). Kljub lastnemu kurdskemu vprašanju je bila med prvimi promotorji delovanja zveze NATO na Balkanu ter aktivno sodelovala v letalskih napadih na ZR Jugoslavijo leta 1999, odprla centre za usposabljanje pripadnikov Osvobodilne vojske Kosova in med prvimi priznala neodvisnost Kosova, vse za simbolično maščevanje Srbiji, krščanski sili, ki je otomansko Turčijo pred skoraj sto leti nagnala z Balkana (Deliso 2007, 105).

»... Balkan je predmet interesa Turčije, to je strateška, politična in družbena resnica, da ne omenjamo gospodarske. To je bil včeraj in je še bolj danes, ko upamo na članstvo v EU ... Vendar, pomen Balkana je ostal ključen, četudi speči, kot strateška vez med Turčijo in Zahodno Evropo, za politično in gospodarsko povezovanje Turčije z Evropo ... Trušč, najprej na Balkanu in kasneje na Kavkazu, ... je postavil Ankaro v položaj, da mora igrati novo, bolj pomembno in prevladujočo vlogo v velikanskem območju od Jadrana do Srednje Azije ... Napačno je misliti, da je problem Kosovo rešen, kljub zaupanju v zvezo NATO in EU ... (Söylemez 2001).

Politika zasedanja pozicij na Balkanu se nadaljuje tudi danes. Albanija, Kosovo ter Bosna in Hercegovina so osrednji del vplivnega območja Turčije. Nedavno lobiranje Turčije pri ZDA, da naj se umaknejo iz procesa ustavnih reform v Bosni in Hercegovini, je bilo neposredno usmerjeno proti entuziazmu EU, da se bo udeležila tega procesa (Stratfor 2009). O vplivu Turčije na Balkanu govori tudi uspešno posredovanje v sporu med državo in Islamsko skupnostjo v Srbiji oziroma v Sandžaku. Tristransko srečanje predsednikov Turčije

\footnotetext{
3 V resnici je poleg Turčije in Rusije tudi EU že s sprejemom Cipra v članstvo postala bikontinentalna političnoteritorialna entiteta, medtem ko bi s sprejetjem Turčije kar močno »posegla« v azijsko celino.
} 
in Srbije ter predsednika predsedstva Bosne in Hercegovine v Carigradu (april 2010) pa je prineslo na dan deklaracijo, v kateri pravijo, da bi morala regionalna politika držav temeljiti na jamčenju za mir, političnem dialogu in zaščiti večetničnih, večkulturnih in večreligijskih značilnosti Balkana. Česar ni mogla doseči EU, je dosegla Turčija, trije člani predsedsva BiH bodo v kratkem obiskali Beograd, predsednik Srbije in predsednik turške vlade bosta skupaj obiskala memorialni park v Srebrenici.

Turško »... 'otomansko-islamsko' sodelovanje« je »usmerjeno v uravnoteženje nasproti pravoslavno-krščansko-slovanskemu bloku na Balkanu« (Ataman 2002), kar v odnose na Balkanu vnaša kulturno-civilizacijsko dimenzijo konfliktnosti. Diplomatske in poslovne aktivnosti Turčije v državah Balkana pa dajo vedeti, da Turčija za politični Zahod že predstavlja 'Drugega' v strukturiranju geopolitičnih interesov v regiji.

\section{TERITORIJA SLOVENIJE IN HRVAŠKE KOT FRONTIER IN MEJIŠČE}

Pri branju političnih in geografskih atlasov bo treba države in njihove teritorialne meje zamenjati s kategorijami točk, stopnjami kontrole in podrejenosti centrov na nižjih ravneh, ki se podrejajo brez zahtev po enakosti in brez prepoznavnosti suverene oblasti, pravi Wæver. Položaj držav bo različen in določen z njihovim položajem v teritorialnih hierarhijah in diferenciran glede na odnos osredij Bruslja, Moskve in Ankare. Praviloma bo pomembnost države $\mathrm{z}$ oddaljenostjo od osredij upadala in stopnja njene suverenosti in neodvisnosti bosta 'naraščala', kar bo povečevalo njen manevrski prostor (Wæver 1997, 79). Vendar, vsako oddaljevanje kake državice na Balkanu od enega osredja jo istočasno približuje enemu ali obema drugima osredjema nove evropske geopolitične strukture.

»Verjetno se nikjer toliko kot v prostoru med EU in Jugovzhodno Evropo ne kažejo hkratni pozitivni in negativni potenciali nove evropske paradigme 'združenosti v različnosti', ki predstavlja obenem zametek prvega postmodernega koeksistenčnega političnega sistema 21. st. in nevarnost neučinkovitega in zbirokratiziranega federalizma vse številčnejših in potencialno konfliktnih 'malih domovin'. Integracijski procesi na našem kontinentu pa so nedvomno prav tradicionalno perifernim evropskim območjem prinesli nove razvojne možnosti,« pravi Bufon $(2004,25)$. Med rezultati sta vsekakor izguba geografije in frontirizacija držav v Jugovzhodni Evropi oziroma na Balkanu.

Teritorij Slovenije je zaradi geografskega položaja »izredno pomembno spojno in prehodno območje glede na velike, gospodarsko in prebivalstveno pomembne evropske celote. V Evropi je malo takšnih prostorov, še manj pa takih, kjer bi se stikale tako pomembne regije, kot so panonska, alpska in sredozemska,« ter najpomembnejše evropske etnične in kulturne grupacije - slovanska, germanska, romanska in ugrofinska (Pavić, 1973, 117), čeprav kot samostojen dejavnik večje geostrateške teže nima (Tunjić 2004, 268-270).

»Prostor, kjer danes živijo Slovenci, $25.000 \mathrm{~km}^{2}$, je samo v tem stoletju pripadal šestim državam ... (Klemenčič in Zupančič, 1994) in je rabil v preteklosti kot mostišče številnih državnih vojsk in sistemov. Vendar je bil teritorij Slovenije edini v SFR Jugoslaviji, ki je bil do začetka 20. st. v celoti robno območje le enega tujega geopolitičnega kompleksa v sistemu 
mark Svetega rimskega cesarstva, Nemške zveze in Cislajtanije, ter ciljni prostor teritorialnih zahtev Italije. Tudi v jugoslovanski državi je imel ta prostor mostiščno, povezovalno in tamponsko vlogo glede na Italijo, Avstrijo in Zahodno Evropo.

Razvoj EU pa je potrdil Rokkanovo paradigmo delitve na jedrna in periferna območja Evrope ter dodatno razgalil položaj držav na robovih EU. »Prav izostanek historično stabilnih centrov oziroma jedrnih območij današnjo Slovenijo pelje po poti od jugoslovanske periferije $\mathrm{k}$ prehodnemu centru ali subcentru ter nazaj k tokrat zahodnoevropski periferiji,« zaključuje Josipovič $(2009,202)$.

Elementi državnosti Hrvaške sežejo daleč nazaj, a se zaradi kompozitne sestave delov pod različnimi tujimi oblastmi $\mathrm{v}$ tradicionalnem mejišču različnih imperijskih struktur in vazalov ter sorazmerne majhnosti niso nikoli uspeli razviti v celoti. Že oblika teritorija Hrvaške je strateško zelo neugodna: ob državnih mejah $56.542 \mathrm{~km}^{2}$ velikega ozemlja je 128 mest in občin s 1900 naselji, kar je petina prebivalstva države, in le dve županiji ter mesto Zagreb nimajo kopenske meje s kakšno sosednjo državo (Strategija... 1997).

O zgodovinski vlogi ozemlja Hrvaške v vlogi frontirja v službi širših političnih, kulturnih, jezikovnih, religijskih, civilizacijskih in drugih teritorialnih sistemov pričajo umestitev in funkcija Vojne krajine. Ta se je od sredine 16. st. kot avstrijska vojaška meja (nem. Militärgrenze) uveljavljala kot predzidje krščanstva (antemurale chritianitatis) in obrambni pas nasproti Osmanski Turčiji. Za habsburško monarhijo je imela geostrateški obrambni in ofenzivni značaj ter pomen, osnovni in trajni cilj njenega vzdrževanja je bil zavarovanje globljega avstrijskega evropskega zaledja z obrambo na globinsko izpostavljenem in tujem ozemlju. Za Avstrijo je ob slabljenju Osmanskega imperija pridobivala Vojna krajina vse bolj vlogo sredstva za oteževanje političnega in gospodarskega razvoja hrvaške državnosti. S postopnim priključevanjem delov civilne Hrvaške, ki so bili pod oblastjo hrvaškega bana, k Vojni krajini je teritorij civilne Hrvaške postal leta 1857 manjši od Krajine. Berlinski kongres leta 1878 je dodelil Avstriji upravljanje Bosne in Hercegovine ter namestitev vojaštva v še vedno osmanskem Sandžaku, s čimer je odpravljen značaj Vojne krajine kot frontirja.

Če poskušamo predstavljene okoliščine razložiti z vidika štirih dimenzij ontologije političnih teritorialnih meja na primeru slovensko-hrvaške meje, je mogoče reči:

- državne teritorialne meje so instrumenti politike. Slovensko-hrvaška meja je predmet spora politik o poteku meje, ki ga poskušata vladi obeh držav doseči vsaka v svojo korist. Koliko je predmet spora tudi funkcija meje, je težko reči. Za to sta vsaj dva razloga: prvi je, da je meja za Slovenijo že zdaj v funkciji dveh teritorialnih sistemov - državnosti Slovenije in hkrati EU nasproti politično 'Drugima', drugi pa je, da je meja za Hrvaško vprašanje zavarovanja teritorialne suvernosti pred vstopom v isti širši teritorialni sistem, v katerem je Slovenija;

- politika in praksa obeh vlad omejujeta nadzor meje de facto. Kljub temu in glede na dejansko odprtost in 'formalni' značaj meje ter razpršenost problema v zvezi z njo je težko zatrditi, da si ena od držav prizadeva za izključne, ekskluzivne vire moči in prednosti vladanja. To bi omogočalo šele zaprtje meje do neprepustnosti za nezaželene zunanje vplive;

- tudi vidike instrumentalizacije meje kot označevalca identitete, četudi so lahko politične identitete večje ali manjše od 'nacionalne' države, je težko pripisati slovensko-hrvaški 
meji, ker nobeden vidik spora ne izraža problema 'zamišljene skupnosti' (Anderson B. 2003), to je nobena od obeh držav ne kaže teženj po etnični argumentaciji premikov poteka državne meje;

- DTM so predmet razprave z vidika prava, diplomacije in politike, ki pa variira od konteksta do konteksta. Predmet takšne razprave je tudi slovensko-hrvaška meja, vendar žal več $\mathrm{v}$ službi akademske in splošne služnosti igram politične moči in nacionalističnih gibanj, manj pa v službi racionalnega in strokovnega pogleda na vprašanje meje.

V primeru slovensko-hrvaške meje bi izjemno težko našli argumente, dejavnike ali vsaj kazalce, ki bi lahko to mejo v polnem pomenu označili kot politično institucijo, funkcijo, proces ali odnos. Meja se ni utegnila izoblikovati s političnimi odločitvami in ni regulirana z običajnimi mednarodnopravnimi akti, ni nastala med nacionalnim oblikovanjem držav, o vprašanju te meje manjka resnih znanstvenih razprav, obenem pa obe državi padeta $\mathrm{v}$ območje obrobja EU in v balkansko mejišče (neo)imperijev.

\section{SKLEP}

Gospodarska, politična, kulturna in varnostna perspektiva Evrope temeljijo na postulatih tradicionalne geopolitike in novega geokonstruktivizma treh evrazijskih razvojnih središč in nosilcev moči. Takšna Evropa mora graditi konstelacijo uravnoteženih odnosov, kar pomeni vračanje $\mathrm{k}$ vzdrževanju stabilnosti in varnosti, ki bo temeljilo na vzdrževanju ravnotežja moči in vpliva $\mathrm{v}$ vmesnem, perifernem in kontaktnem območju Jugovzhodne Evrope oziroma Balkana. V tej luči Balkan ne more biti kaj drugega kot 'okolje transformacije' (fr. un milieu de transformation), kot ga je nekoč v vlogi mejišča videl Fawcet (1918). Območje se pretvarja v šop državic, Kleinstaaterei, kot so nekoč rekli nastanku Vmesne Evrope, mejišče kot sistem periferij, frontirjev, mark, tamponov, krajin oziroma psevdo, kvazi, uporniških, geto in šarnirskih držav. Tako Balkan nadaljuje svojo geopolitično usodo med evropsko, evroatlantsko in evrazijsko perspektivo ter vlogo laboratorija evropske družbene in prostorske integracije in dezintegracije. Geografsko, geopolitično in geostrateško ostaja Balkan mejišče hkrati med dvema Evropama ter med Evropo in Azijo.

Če se je »... z nastankom slovensko-hrvaške meje celotna Slovenija spremenila v obmejno regijo « (Klemenčič 2001, 13-14), se bo z vstopom Hrvaške v EU enako zgodilo celotnemu geografskemu (in političnemu) prostoru obeh držav. Še več, z oporo na načelno strukturo imperijskega sistema je mogoče še natančneje opredeliti njun funkcionalni položaj $\mathrm{v}$ teritorialnem sistemu EU. Kot sta bili nekoč ozemlji obeh držav (in Madžarske) območje periferije habsburške monarhije, danes zavzemata enaki mesti na hierarhični lestvici teritorialnega sistema EU. Ozemlje Slovenije je še mogoče uvrstiti v krog dominionov (nekoč nemških mark in Cislajtanije) ali sorazmerno avtonomnih oblasti, ki priznavajo nesporno vrhovništvo centra v Bruslju. Ozemlje Hrvaške, nekoč habsburška Vojna krajina, pa pade $\mathrm{v}$ krog hegemonije, $\mathrm{z}$ notranjo neodvisnostjo, vendar $\mathrm{z}$ omejitvami na področju zunanje politike, vsekakor pa s prepovedjo (lastne) vojne s sosedi.

$\mathrm{S}$ strateškega vidika ozemlji obeh držav padeta $\mathrm{v}$ dvostopenjsko, vendar enotno geostrateško pročelje EU oziroma varnostni glacis, katerega funkcije bodo valovale v 
odvisnosti od dinamike geopolitičnih odnosov med osredji. V takšnih odnosih se meja vrača k svoji historičnosti oziroma k značilnostim in funkcijam, kakršne je imela nekdanja meja med Cislajtanijo in Translajtanijo. Vendar spor med državama glede na ostrino izstopa $\mathrm{v}$ delu, kjer te meje ni bilo niti v obdobju Avstro-Ogrske, oziroma kjer sta bili tudi v dvojni monarhiji v veljavi kopenska in jadranska maritimna kontinuiteta Avstrije vse do črnogorske Boke kotorske.

Politična geografija bo lahko še naprej brala slovensko-hrvaško mejo na političnih zemljevidih, vendar ta meja ne bo več uporabna kot referenca za razlaganje političnega razvoja sosednjih držav. Ozemlji obeh držav se utapljata v frontirju blokovske identitete in geopolitične subjektivitete EU nasproti revitaliziranima geopolitičnima subjektivitetama Rusije in Turčije.

Prav tako ne bo mogoče govoriti o pregradni funkciji slovensko-hrvaške meje v standardnem političnogeografskem formatu. »Pregradne funkcije meje so močnejše, ko meja ne ločuje samo dveh držav, ampak tudi dva nasprotujoča si vojaška in/ali gospodarska bloka« (Kolossov in O’Loughlin 1999). Pregradna funkcija slovensko-hrvaške meje se z vstopom Hrvaške v EU premika nekoliko $\mathrm{v}$ teritorialno globino balkanske Evrope, kar dodatno zmanjšuje pomen državne meje. Ali to obenem za politično geografijo pomeni, da ne bo mogla več govoriti o čezmejnih, primejnih ali obmejnih območjih, ki bi bila pomembneje povezana z identitetama Slovenije in Hrvaške?

Političnogeografsko bo relevanten pogled iz prostorske perspektive, politično pa iz Bruslja in ne iz Ljubljane ali Zagreba. Državne teritorialne meje v obravnavani geopolitični strukturi štejejo le malo, kolikor pač štejejo, pa je stopnja njihove konfliktnosti relevantna le za sosednji državici. Vprašanje, »čigava skrb je slovensko-hrvaška državna teritorialna meja«, je odveč.

»... Pred nami so kaotični vozli, rešiti bi se jih dalo samo gordijsko. Z mečem. Vendar, meči so v rokah onih, ki te vozle zapletajo. Pot do razpletanja je skrivnostno težka in oddaljena ...«, je zapisal Miroslav Krleža v zagrebških nočeh davnega leta 1917, med tem, ko je osluškoval odmevanje artilerijskih plotunov na soški fronti in opazoval neskončne kolone živih mrtvecev, ki so prihajali s front in odhajali nanje, neznano kam in neznano za kaj. Zapisane besede so pod naslovom $\mathrm{O}$ hrvaštvu, lahko bi bile tudi $\mathrm{O}$ slovenstvu.

»Naj mali mislijo, da vodijo politiko, tako je lažje«, je del dialoga diplomatov Beneške republike, Osmanskega cesarstva in Avstrije, ki so se 'spopadli' na nemirni meji, ki je delila Zahod od Vzhoda ter krščansko Evropo od islama, kot to odlično ilustrira film Branka Ivande Konjenik.

\section{Viri in literatura}

Aalto, P. 2002: Structural geopolitics in Europe: constructing geopolitical subjectivity for the EU and Russia. Working Paper No. 22, COPRI.

Agnew, J. 1999: Mapping political power beyond state boundaries: territory, identity, and movement in world politics. Millennium 28, 3, 499-521. London

Anderson, B. 2003: Imagined communities: reflections on the origin and spread of nationalism. London. 
Anderson, J. 2007: Singular Europe: an empire once again? V: Armstrong, W in Anderson, J. (ur.) Geopolitics of European Union enlargement. The fortress empire, 9-29. London, New York.

Anderson, M. 1996: Frontiers. Territory and state formation in the modern world. Cambridge.

Ataman, M. 2002: Leadership change: Özal leadership and restructuring in Turkish foreign policy. Alternatives. Turkish journal of international relations 1, 1.

Bahr, E. 2007: Europe's strategic interests. Europe's World. IP global.

Bora, T. 1995: Milliyetçiliðin Kara Baharý. Istanbul. Birikim Yayýnlarý.

Brzezinski, Z. 1997: The Grand chessboard. American primacy and its geostrategic imperatives. New York.

Buchanan, A., Moore, M. 2003: States, nations, and borders. The ethics of making boundaries. Cambridge.

Bufon, M. 2004: Med Evropsko unijo in Jugovzhodno Evropo: prostor družbenih integracij in dezintegracij. Uredniška beseda. V: Bufon, M. (ur.) Slovenija po letu 2004. Mostišče med EU in Jugovzhodno Evropo, 19-29. Koper

Chaliand, G., Rageau, J. P. 1986: Strategic atlas, world geopolitics a new and exciting survey of the political realities of today's world. London.

Cohen, B. S. 1999: The geopolitics of an evolving world system: from conflict to accommodation. V: Diehl, F. P. (ur.) a road map to war, territorial dimensions of international conflict, 271-298. Nashville, London.

Cohen, B. S. 2002: Geopolitics of the world system. Boston.

Cviic, C., 1997: The new balance of power in south-eastern europe: notes towards a provisional assessment. V: Tunander, O., Baev, P., Einagel, I. V. (ur.) Geopolitics in post-wall Europe: security, territory and identity, 217-234. Oslo.

Deliso, C. 2007: The coming balkan caliphate: the threat of radical islam to Europe and the West.

Fawcett, C. B. 1918: Frontiers: a study in political geography. Oxford.

Foucher, M. 1998: The geopolitics of European frontiers. V: Anderson, M. and Bort, E. (ur.) The Frontiers of Europe, 235-250. London, Washington.

Galtung, J. 1996: Peace by peaceful means: peace and conflict, development and civilization. Oslo.

Grčić, M. 1989: Opšta politička geografija. Beograd.

Hassner, P. 1997: Obstinate and obsolete: non-territorial transnational forces versus the European territorial states. V: Tunander, O., Baev, P., Einagel, I. V. (ur.) Geopolitics in post-wall Europe: security, territory and identity, 45-58.. Oslo.

Hay, W. A. 2003: Geopolitics of Europe. Medmrežje: http://www.fpri.org/orbis/4702/hay. geopoliticseurope.html (10.5.2010).

Huntington, P. S. 1998: Sukob civilizacija i preustroj svjetskog poretka. Zagreb.

Ivanda B. 2003: Konjanik. Film po romanu Ivana Aralice. Zagreb.

Josipovič, D. 2009: Razprava o odnosu center-periferija: peripanonski slovensko-hrvaški stik v sistemu širitve EU. V: Gosar. A. (ur.) Razvojne priložnosti obmejnih območij Slovenije (Development opportunities of Slovenian border regions), 197-211. Koper. 
Kennedy, P. 1987: The rise and fall of the great powers: economic change and military conflict from 1500 to 2000. London.

Klemenčič, V. 2001: Slovensko hrvaška obmejna regija in njene funkcije v povezovanju med Hrvaško in Slovenijo in v luči Evropske integracije. Dela 16, 7-16. Ljubljana.Klemenčič, V. 2009: Sodobni problemi geopolitičnega položaja Slovenije s posebnim poudarkom na obmejnih območjih. V: Gosar. A. (ur.) Razvojne priložnosti obmejnih območij Slovenije (Development opportunities of Slovenian border regions), 29-41. Koper

Klemenčič, V., Zupančič, J. 1994: Borderlands and regionalism in the space settled by Slovenians - a case study. V: Koter, M. (ur.) inner divisions. region and regionalism. Łodż, Opole.

Kolossov, V. A., O'Loughlin, J. 1998: new borders for new world orders: territorialities at the fin-de-siecle. GeoJournal 44, 3, 259-273. Dordrecht.

Kolossov, V., O'Loughlin, J. 1999: Pseudo-states as harbingers of a new geopolitics: the example of the Trans-Dniester Moldavian Republic (TMR). V: Newman, D. (ur.) boundaries, territory and postmodernity, 151-176. London, Portland.

Laitinen, K. 2003: Geopolitics of the northern dimension: a critical view on security borders. Geopolitics 8, 1, 20-44. London.

Lavrov, S. 2007: The foreign policy of Russia: a new phase. The Journal Expert, on December 17, 2007. (Ministry of Foreign Affairs of the Russian Federation. Information and Press Department . Medmrežje: http://www.mid.ru/Brp_4.nsf/arh/ 969279EE85A9B046C32573B60048C175?OpenDocument (10.5.2010).

Leicht, J. 1999: Zašto Turska podržava rat protiv Srbije? Medmrežje: http://www.wsws.org/ sh/1999/maj1999/turk-m26.shtml (januar 2010)

Magocsi, R. P. 2002: Historical atlas of East Central Europe. Vol. I. Washington.

Mahbubani, K. 2009: Be quick Europe, or miss out on the Asian century. IP International.

Matić, B. (ur.) 1995: Tajna Balkana. Monografija o geopolitici. Beograd.

Mearsheimer, J. J. 1990: Back to the future: instability in Europe after the cold war. International Security 15, 1, 5-56. Cambridge.

Pavić, R. 1973: Osnove opće i regionalne političke geografije, geopolitike i geostrategije. I. dio. Zagreb.

Pavić, R. 1989: Definicija i razlikovanje međa i granica. Geografski horizont 36, 1-4, 51-53. Zagreb.

Paasi, A. 1999: Boundaries as social processes: territoriality in the world of flows. V: Newman, D. (ur.) Boundaries, territory and postmodernity, 69-88. London, Portland.

Posener, A. 2007: Imperium der Zukunft. Warum Europa Weltmacht werden muss? München.

Povijest svijeta - od početka do danas, 2. izd. Zagreb 1990.

Ratzel, F. 1897: Politische Geographie. Berlin.

Rokkan, S., Flora, P., Kuhnle, Derek, S., Urwin W. 1999: State formation, nation-building, and mass politics in Europe. Oxford.

Rupnik, J. 1994: After Communism: What. Daedalus. Journal of the American Academy of Arts and Science 123, 3, 90-114. 
Söylemez, Y. 2001: International Terrorism, Turkish interests in the Balkans and the stability pact. Akdeniz İ. İ. B. F. Dergisi (2) 2001, 144-146.

Strategija prostornog uređenja Republike Hrvatske. Ministarstvo Prostornog uređenja, graditeljstva i stanovanja. Zavod za prostorno planiranje. Zagreb 1997.

Stratfor 2009: EU: rapidly expanding into the Balkans.Medmrežje: http://www.stratfor.com/ node/149009/analysis/20091117_eu_rapidly_expanding_balkans (10.5.2010).

Taylor, J. P. 1997: Political geography: world-economy, nation state and locality. Harlow.

Thomann, P. P. E. 2010: Europe as a political force: cards on the table. La revue géopolitique online. Medmrežje: http://www.diploweb.com/Europe-as-a-political-force-cards.html (12.5.2010).

Tunander, O. 1997: Post-cold war Europe: synthesis of a bipolar friend-foe structure and a hierarchic cosmos-chaos structure? V: Tunander, O., Baev, P., Einagel, I. V. (ur.) Geopolitics in post-wall Europe: security, territory and identity. Oslo.

Tunjić, F. 2003: Vmesna Evropa - naša realnost: kritika obstoječih paradigem. Ljubljana. Geografski vestnik 75, 1, 59-71. Ljubljana.

Tunjić, F. 2004: Vmesna Evropa. Konfliktnost državnih teritorialnih meja. Koper.

Tunjić, F. 2004a: Državne teritorialne meje v Vmesni Evropi z vidika nekaterih temeljnih značilnosti: primer uporabe metode hierarhičnega razvrščanja. Annales, series historia et sociologia 14, 1,109-128. Koper.

Tunjić, F. 2007: Međueuropa - paradigma političke geografije geopolitike. Na Zapadu ništa novo, na Istoku sve po starom. Društvena istraživanja 16, 4-5, 90-91. Zagreb.

Tunjić, F. 2009: Evropska sosedska politika. V: Kajnč, S., Lajh, D. (ur.) Evropska unija od A do Ž, 99-104. Ljubljana.

Tunjić, F. 2009a: Reteritorializacija Evrope: reteritorializacija obrambe in varnosti države - primer geoprostora nekdanje Jugoslavije. V: Gosar, A. (ur.) Razvojne priložnosti obmejnih območij Slovenije. Koper.

Vukadinović, R. 1995: Konflikt v nekdanji Jugoslaviji in balkanska varnost. Teorija in praksa 32, 3-4, 270-282. Ljubljana.

Wæver, O. 1997: Imperial metaphors: emerging European analogies to pre-nation-state imperial systems. V: Tunander, O., Baev, P., Einagel, I. V. (ur.) Geopolitics in post-wall Europe: security, territory and identity, 59-93. Oslo.

Webb, W. P. 1952: The great frontier. New York.

Wijnants, E. P. 2006: http://sociologyesoscience.com/nextyears7.html (11.6.2009).

Winrow, G. M. 1995: Geopolitics and geoculture: Turkey and Central Asia. Prezentacija na mednarodnem seminarju Central Asian geopolitics, tendencies and transformation na Punjab University, Chandigarh.

Jenkins, F. 2007: Europe's christian comeback. Foreign policy. Medmrežje: http://www. foreignpolicy.com/articles/2007/06/11/europes_christian_comeback (17.5.2010)

Zupančič, J. 2009: Političnogeografska analiza Balkana. Dēa 32, 85-134. Ljubljana.

Zupančič, J. 2006: Geografski pristopi k proučevanju kriznih območij. Dela 26, 161-179. Ljubljana. 


\title{
STATE TERRITORIAL BOUNDARY AT THE EDGE OF THE EUROPEAN UNION: FRONTIERISATION OF SLOVENIA-CROATIA TERRITORY
}

\begin{abstract}
Summary
The paper concerns with the settlement issue of the Slovenian-Croatian state territorial boundary (STB) delimitating the territories of the two countries 'plunging' into the EU frontierisation against the two other 'new' European empires - Russia and Turkey that participate in the Balkan's convergence area of all the three. Therefore, the clarification of the boundary issue between the countries should be sought on the European and Eurasian and not on local level.

The two starting points of the analysis are in for a - 'post-sovereign realism' (Wæver 1997) and 'back to the future' (Mearshemer 1993): the first that the nation-state is no longer the all-dominant form, sovereignty does not control the system and the second that the 'new' geography of the Balkan's future is being caught in the way to the past. Looking back to Ratzel's political geography author reminds that frontier is composed of three peripheral territorial belts - two border belts of territories of neighboring countries divided by the medium territorial belt between them, where states are intermingling. Ratzel worked in time of Europe of empire's and he could not think in the spirit of later understanding of state where merely boundaries. Nevertheless, it would be difficult to negate the value of his arguments for the present time of the neoimperialization of Europe. Later, for Rokkan, a relation between 'centres' and 'periphery', and 'peripheries' was also a key component of the European territorial structure of political systems that are developed in a process of territorial expansion. In his differentiation of 'centrality' and 'peripheriality' from statehood in a historical perspective, Slovenia and Croatia and other Balkan states can be found only as components of the eastern peripheral territories, or intermediate and dispute areas between East and West Europe and between Europe and Asian Turkey.

Geopolitics has been developed as a concept in Europe and it includes relationships between power, resources, and space. Nowadays, the EU, Russia and Turkey, historically the three main European powers, are »mapping the main structural developments and processes in contemporary Europe in the sphere of spatially and geographically coloured politics, i.e. geopolitics« (Aalto 2002). Hence, it is convenient to speak about renovation of the tripartite cosmology of the Western Europe that is the Catholic-Protestant Roman-Germanic EU towards the Russian Orthodox Slavs, and both of these against the Turkish Islamic Union, all three with strong gravitation Centres in Galtung's terms.

Beside that, whether the EU is to be serious political player it needs to devise where a geopolitical strategy based on its territorial interests. »In defining its boundaries, geographical priorities and alliances, the ability to bring its weight to bear in the world order will be greatly enhanced «, sounds one of the very fresh calls from Brussels (Thomann 2010).

However, in the EU they are aware that they can realize their strategic visions to become the actor of global strategic flows only by taking Russia into account (Posener 2007). Similar is with Turkey, although weaker power, but strategically of similar importance. Both are bi-
\end{abstract}


continental Eurasian powers that ruled over Europe and through the 'Concert of European Powers' maintained the Europe's order. Beside that, relations between Russia and Turkey and Russian-Turkish wars were always also the wars of other European powers - Great Britain, France, Austria-Hungary, Germany, Italy. Russia was the actor of all Turkish defeats, and vice versa.

Instead, such Europe cannot do nothing else than maintain the constellation of power, interests and influences. For the Balkan's area and its parts 'in between' and on the Empires' edges it inevitable means going 'back to the future'. In this light, the Balkan is transforming to the node of frontiers over which the interests, influences, and even rules of the three European empires are intermingling.

In such hubs of frontiers, as a rule, importance of countries decreases and degree of their sovereignty increases proportionally to their distance from the Centres. However, in the Balkans step of each country away of one centre brings this country closer to the other one or both Centres. That means that the position of such states depends on in which radial round of each Centre it is located and where it is in the system as a whole.

The development of the EU confirmed Rokkan's paradigm of division to centres and peripheral areas of Europe and additionally bared the peripheral and the edge position of the country. »Just absence of historical stable centres that is the core area drives today's Slovenia through from Yugoslav periphery to transitional centre or sub-centre, and back, this time, to the West-European periphery« Josipovič concludes (2009, 202).

Elements of the statehood of Croatia reach back for centuries but because of composite structure under different foreign rulers being traditionally frontier of imperial structures and vassals it has never developed in wholeness. Nowadays, territory of Croatia is strategically very unpleasant: along state boundaries of $56,542 \mathrm{~km}^{2}$ there are 128 towns and municipalities with 1900 settlements and with one fifth of inhabitants while only the two counties and Zagreb do not border with neighboring states. Historically, as the Military frontier (Ger. Militärgrenze), Croatian territory served from the middle of $16^{\text {th }}$ century as the Christian bulwark (antemurale christianitatis) and Austria's, later the Austro-Hungarian Monarchy's Military frontier against Ottoman Turkey.

If accession of Slovenia in the EU put its territory into the EU borderland (Klemenčič 2001, 13-14), the same will happen to the territory of Croatia after the country enters the EU. Regarding the principle structure of imperial systems, it is possible to see the functional positions of both state territories. As were both (together with Hungary) at one time the peripheries of Habsburg Monarchy, today, they occupy the similar places on the hierarchical scale of territorial system of the EU. The territory of Slovenia has been fallen into the orbit of dominions that is of limited autonomies, acknowledging the Heads in Brussels with no dispute. The territory of Croatia, being Habsburgs' Military frontier in times past, now falls into a belt of hegemonies, with the internal independence but with limited foreign politics and interdiction of (its own) war with neighbors.

Strategically, the both territories fall into two-degree but united the EU geostrategic facade or the security glacis whose function will wavering dependent on dynamics of geopolitical relations between the Centres. In such relations, the Slovenian-Croatian state boundary is coming back to its historic nature that is to similarities of its functioning being 
the land boundary between Cisleithania and Transleithania at one time. However, acuteness of the dispute between the two countries is connected with delimitation of the Bay of Piran, which has never been delimited.

With accession of Croatia to the EU the EU security-strategic border will be moved deeper into the Balkan. This is what additionally reduces its importance. Political geography won't be able any more to talk about borderland area(s) that would be stronger linked to the identities of the two countries - Slovenia and Croatia and this boundary will not be used as a reference for examination and explanation of political development of neighboring countries. It is more than clear that state territorial boundaries in proceeded territorial structure count a little, and what they count the degree of their conflictness is perhaps relevant only for neighboring countries. Politically, a view from Brussels, will be relevant, not from Ljubljana or/and Zagreb.

»Let to the small think that they make a politics, so it is easier«, is a piece of the dialogue between 'clashed' diplomats of Venetian Republic, the Ottoman Empire and Austria on the unruly and uneasy frontier that had been dividing the West from the East, and the Christian Europe from Islam«, as it is excellent illustrated in the movie 'Konjanik' (The Rider) by Branko Ivanda. 